\title{
Pelatihan Penggunaan Alat Hurdle drills dan Ladder Drills Bagi Guru Pendidikan Jasmani Dalam Pembelajaran Penjas di Kota Kupang Provinsi Nusa Tenggara Timur
}

\author{
Yudabbirul Arif*1, Michael J. H. Louk ${ }^{2}$, Jurdan Martin Siahaan ${ }^{3}$, \\ Erwin S Neolaka ${ }^{4}$, Intan Kamala Aisyiah \\ ${ }^{1234}$ Universitas Nusa Cendana, \\ ${ }^{5}$ Universitas Baiturrahmah \\ E-mail: yudabbirul@staf.undana.ac.id
}

\begin{tabular}{l}
\hline Article History: \\
Received:Oktober \\
2021 \\
Revised: Oktober \\
2021 \\
Accepted: \\
November 2021 \\
Available \\
online:Desember \\
2021
\end{tabular}

Keywords:

Hurdle drills, Ladder Drills, Pelatihan
Abstract: Kemungkinan besar siswa ini akan kurang motivasi untuk berolahraga atau tetap bugar karena pengalaman negatif mereka dalam pendidikan jasmani atau atletik. Hal lainnya yang sering terjadi ialah adanya keterbatasan guru penjasorkes di lingkup sekolah dasar, dimana karena keterbatasan guru penjasorkes. Target yang ingin dicapai tentunya adalah untuk meningkatkan SDM dari guru pendidikan jasmani. Manambah wawasan guru pendidikan jasmani dan guru mata pelajaran lain yang mengajar mata pelajaran pendidikan jasmani di Sekolah Dasar ligkup Kota Kupang Nusa Tenggara Timur tentang Penggunaan Sarana hurdle drills dan leader drills dalam melatih pergerakan dan kesiapan kondisi fisik peserta didik yang mengikuti pembelajaran pendidikan jasmani tanpa rasa takut dan trauma. Metode yang digunakan ada 3 tahapan penigkatan pengetahuan, peningkatan kecakapan, dan pendukungan serat pendampingan. Adapun implementasinya perlu dilakukan secara terencana, bertahap, dan berkelanjutan, yang pada gilirannya siswa diharapkan dapat meningkatkan sikap positif bagi diri sendiri dan menghargai manfaat aktivitas jasmani bagi peningkatan kualitas hidup. Pemberian alat-alat berupa Hurdle drills, Ladder Drills untuk pelaksaannya didalam pendidikan jasmani. 


\section{Pendahuluan}

Salah satu visi misi program studi pendidikan jasmani kesehatan dan rekreasi adalah untuk membentuk kebugaran jasmani (Yusollina \& Suwanda, 2020). Aktifitas kebugaran fisik yang teratur dapat memperbaiki kesegaran jasmani sehingga badan dapat berfungsi secara efisien dan optimal untuk melakukan tugas sehari- hari (Arif, 2020; Santika et al., 2020; Piyana, et al., 2020; Padmawan et al., 2020). Kebugaran jasmani tidak hanya punya keuntungan secara pribadi, tetapi juga memberikan keuntungan bagi masyarakat dan negara. Oleh karena itu kegiatan olahraga sekarang ini semakin mendapat perhatian yang luas. The knowledge and skills acquired in health education and physical education form an integrated whole that relates to the everyday experiences of students and provides them with the physical literacy and health literacy they need to lead healthy, active lives (Sullivan, 2015). Dikatakan bahwa Pengetahuan dan keterampilan yang diperoleh dalam pendidikan kesehatan dan pendidikan jasmani merupakan satu kesatuan yang terintegrasi yang berhubungan dengan pengalaman sehari-hari siswa dan membekali mereka dengan literasi jasmani dan literasi kesehatan yang mereka butuhkan untuk menjalani hidup yang sehat dan aktif.

It forces us to teach to the curriculum instead of teaching to the students (Brad Stulberg, 2017).Dikatakan kurikulum merupakan menjadi acuan untuk mencapai tujuan pendidikan jasmani secara umumnya, begitu juga dalam pendidikan olahraga. The training provided must be quite heavy and must be carried out repeatedly with a high enough intensity (Arif et al., 2019; ). Jadi dengan diberikannya alat maka harus dilakukan secara berkesinambungan agar tercapainya kebugaran bagi peserta didik.

Guru pendidikan jasmani dengan kompetensi yang dimiliki diharapkan mampu memodifikasi sarana dan prasarana pembelajaran yang dapat merangsang anak didiknya untuk melakukan aktifitas fisik dalam pembelajaran dengan senang hati sehingga pembelajaran pendidikan jasmani akan dirasakan menyenangkan (Setiyawan, 2017). Sarana dan prasarana yang digunakan harus sesuai dengan kebutuhan aktifitas belajar dan usia peserta didik pendidikan Jasmani adalah suatu proses pembelajaran melalui aktivitas 
jasmani yang didesain untuk meningkatkan kebugaran jasmani, mengembangkan keterampilan motorik, pengetahuan dan perilaku hidup sehat dan aktif, sikap sportif, dan kecerdasan emosi (Ruslan, 2011).

Di provinsi Nusa Tenggara Timur khususnya di Kota Kupang, terdapat beberapa persolan yang kerap muncul dalam pembelajaran pendidikan jasmani. Salah satunya ialah berkaitan dengan penyelenggaran pembelajaran dengan metode mengajar guru yang masih cenderung monoton atau masih menggunakan cara-cara lama seperti pada kegiatan awal pemanasan siswa masih diberikan pemanasan dengan cara berlari keliling lapang sampai peserta didik berkeringat dengan cuaca di kota kupang yang ketika pagi hari pukul 09.00 wita suhu udara sudah mencapai 36-37 derajat.

There is no better environment for nurturing emotional skills in students than physical education and sport (Anderson \& Glover, 2017). Maksud dari kutipan diatas dikatakan bahwa lingkungan yang lebih baik untuk memelihara keterampilan emosional pada siswa daripada pendidikan jasmani dan olahraga. Kondisi ini membuat peserta didik mengalami trauma, sehingga pada pertemuan berikutnya peserta didik sering beralasan untuk tidak mengikuti pembelajaran penjasorkes.

Kondisi tersebut hanya merupakan salah satu dari sekian persoalan yang ada dalam penyelenggaraan pembelajaran pendidikan jasmani di Sekolah terutama di lingkup sekolah dasar. It's more likely that these students will lack the motivation to exercise or stay fit due to their negative experiences in physical education or athletics (Harrison, 2017). Dikatakan bahwa Kemungkinan besar siswa ini akan kurang motivasi untuk berolahraga atau tetap bugar karena pengalaman negatif mereka dalam pendidikan jasmani atau atletik.

Hal lainnya yang sering terjadi ialah adanya keterbatasan guru penjasorkes di lingkup sekolah dasar, dimana karena keterbatasan guru penjasorkes maka tugas mengajar mata pelajaran penjasorkes kerap kali diberikan kepada guru bidang studi lain untuk mengajar pelajaran penjasorkes. Semua ini bertujuan untuk perkembangan pendidikan jasmani di sekolah dan praktisi olahraga di dalam metode dan alat dari pembelajaran itu sendiri di 
Nusa Tenggara Timur Dari sedikit gambaran persoalan dalam pembelajaran penjasorkes yang terjadi di provinsi Nusa Tenggara Timur khususnya Kota Kupang, maka sebagai akademisi kami berencana membuat pelatihan penggunaan media pendukung seperti hurdle drills dan leader drills dalam pembelajaran penjasorkes bagi guru penjasorkes dan guru bidang studi lain yang mengajar mata pelajaran penjasorkes di Kota Kupang Provinsi Nusa Tenggara Timur. Alat ini berguna bagi atlet/siswa untuk mengembangkan kemampuan motoric sehingga tumbuh kembangnya akan semakin baik (Sumarsono, 2019).

\section{Metode}

Sasaran kegiatan ini adalah guru di kota kupang. Pemilihan dan penetapan sasaran Workshop dan pelatihan ini mempertimbangkan permasalahan aktual yang dihadapi oleh sekolah kota kupang.

Dengan adanya pelatihan ini diharapkan dapat memberikan meningkatkan pengetahuan, pemahaman, ketrampilan serta kemampuan bagi guru di kota kupang dalam program latihan dan penanganan cidera, sehingga berefek pada peningkatan kemampuan motorik siswa.

Metode Pelaksanaan yang digunakan dalam pelatihan ini adalah sebagai berikut :

\section{Metode Ceramah}

Metode ceramah digunakan untuk menjelaskan teori-teori dasar dan pengetahuan tentang Hurdle drills dan Ladder Drills. Selain itu, metode ini juga diberikan untuk memberikan pengetahuan dan pemahaman tentang manfaat dari penggunaan alat tersebut. Metode ini diberikan pada tiap awal pembahasan pokok bahasan, yang bertujuan untuk memberikan dasar- dasar teori tiap pokok bahasan baru.

\section{Metode Demonstrasi}

Metode ini diberikan untuk menjelaskan penggunaan tiap-tiap alat Hurdle drills dan Ladder Drills. Baik dalam menguasai materi, memberikan penugasan, dan juga memberikan penilaian terhadap guru dalam 
melaksanakan latihan ini. Diharapkan dengan metode ini pemahaman peserta terhadap masing-masing materi makin mendalam.

\section{Metode Praktik}

Pada metode ini peserta mempraktikkan semua materi yang sudah didapatkan sebelumnya. Metode ini digunakan untuk mengetahui sejauh mana tiap peserta mampu mengaplikasikan ilmu yang telah didapat.

\section{Hasil}

Hasil dan luaran yang dicapai dari kegiatan ini adalah mitra memahami bagaimana menciptakan pembelajaran aktif dan menyenangkan dengan menggunakan alat hurdle drils dan ledder drils sehingga siswa dapat lebih termotivasi didalam melaksanakan kegiatan pembelajaran.

Persiapan

Kegiatan Pelatihan Penggunaan Alat Hurdle drills dan Ladder Drills Bagi Guru Pendidikan Jasmani Dalam Pembelajaran Penjas di Kota Kupang Provinsi Nusa Tenggara Timur ini berisi kegiatan teori dan praktek, tempat pelaksanaannya dilakukan di sekolah dasar citra bangsa yang dilakukan secara face to face atau tatap muka lansung. Untuk kegiatan di undang dengan 35 peserta yang mana telah menggunakan protokol kesehatan yang optimal. Semua berasal dari unsur guru yang telah dibekali pengetahuan dasar.

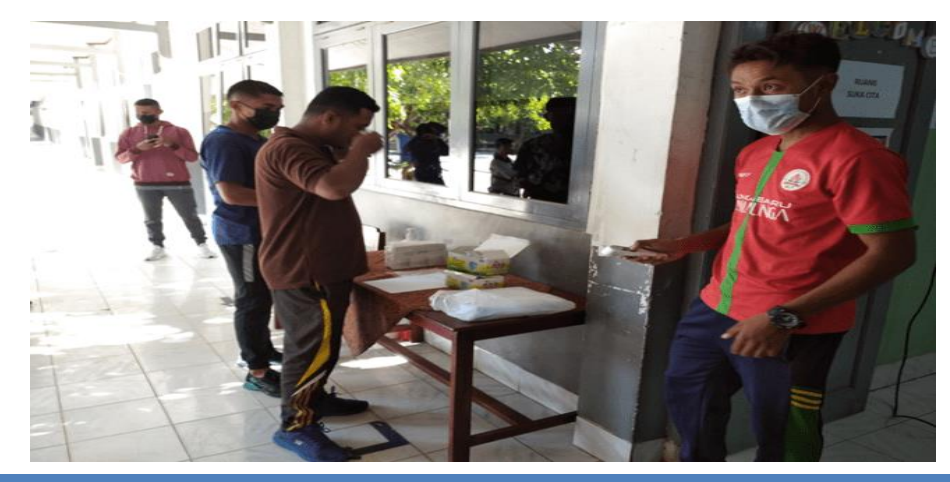




\section{Gambar 1. Prokes covid 19}

Semua orang yang terkait dari pengabdian ini harus bersedia untuk mengikuti prokes yang menjadi standar pemerintah baik itu guru, dosen, mahasiswa, dan panitia sekalipun. Untuk prokesnya kita menyediakan sabun cuci tangan, masker, hands sanitaiser.

Pelaksanaan

Tahap kedua dalam kegiatan pengabdian ini adalah tahap pelaksanaan. Pelaksanaan Pengabdian Kepada Masyarakat Pelatihan Penggunaan Alat Hurdle drills dan Ladder Drills Bagi Guru Pendidikan Jasmani Dalam Pembelajaran Penjas di Kota Kupang Provinsi Nusa Tenggara Timur dilaksanakan dengan menyampaikan pematerinya Erwin Sneolaka M.Pd dan juga merupakan orang kepelatihan serta memiliki lisensi di berbagai cabang sehingga pemteri merupakan seseorang ahli dalam pelaksanaan ini. Koordinasi dilakukan untuk menentukan waktu pelaksanaan, tempat pelaksanaan, pendanaan yang dibutuhkan, serta menyiapkan materi ajar yang sesuai dengan judul pengabdian ini.

Pelaksanaan program latihan dan terapi cedera olahraga bagi guru dan pelatih di kota kupang membutuhkan waktu sebanyak 15 JP teori dan praktek. Proses pelatihan berjalan dengan tertib dan lancar. Para peserta mengikuti pelatihan dengan antusiasme yang tinggi. Ini dapat dilihat dari pembelajaran tatap muka lansung dari kehadiran peserta serta Tanya jawab yang dilakukan. 
Dharma Raflesia

Jurnal Ilmiah Pengembangan dan Penerapan IPTEKS

Vol. 19, No. 02, Desember, 2021, pp. $346-355$

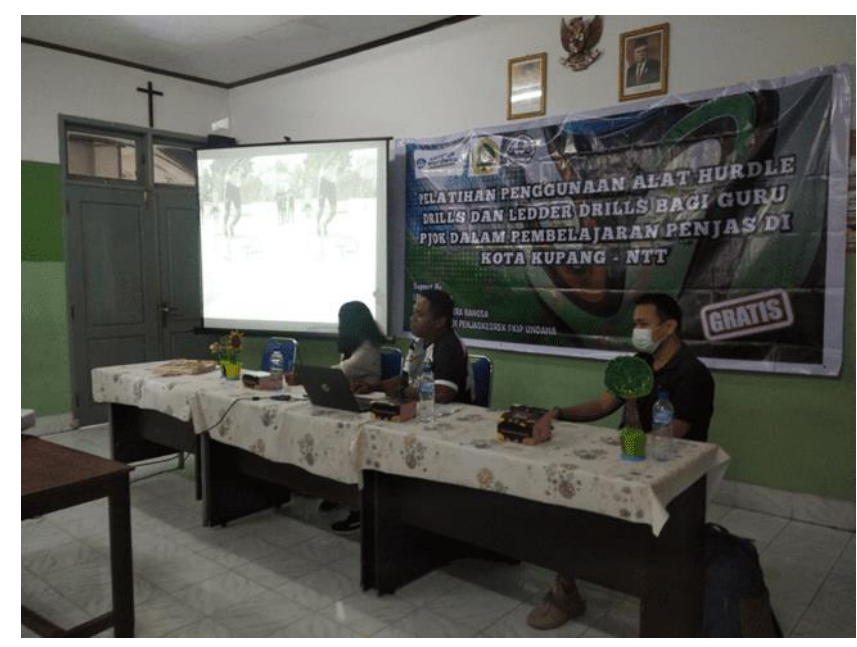

Gambar 2. Pemaparan oleh pemateri

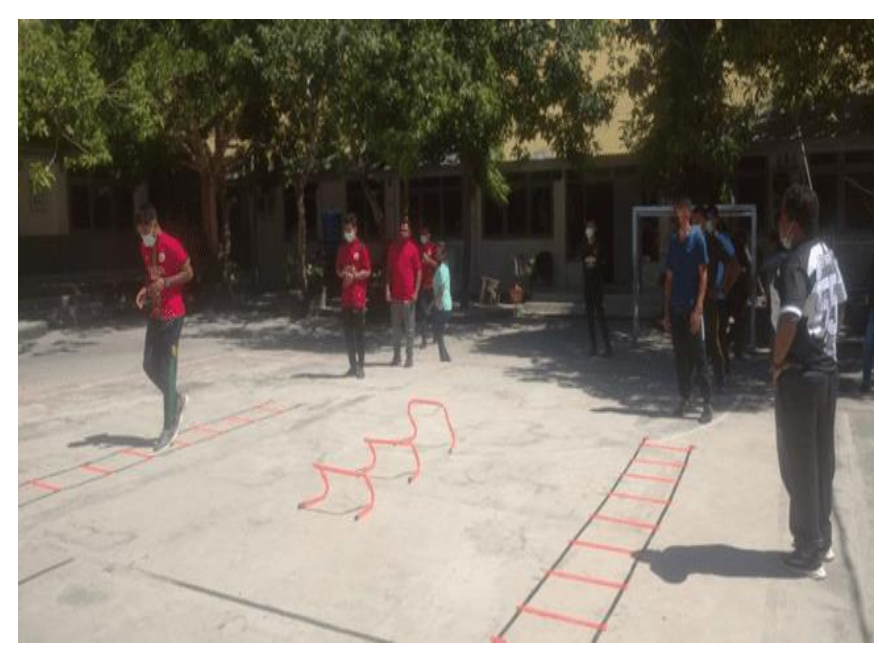

Gambar 3. Praktek lansung

Mitra mampu mempraktekan apa yang telah di jelaskan pemateri. Dengan pemahaman tersebut mitra mampu melakukan praktek Hurdle drills dan Ladder Drills dengan baik serta dengan teknik yang bagus. Sehingga jika di ajarkan kepada siswa nya akan bisa memberikan manfaat yang luar biasa untuk perkembangan motorik siswa. 
Dengan pemahaman tersebut mitra mampu meng aplikasikan teori ini didalam pembelajaran baik itu secara daring karna masih berada didalam situasi pandemi, maupun nantinya bisa dilakukan secara face to face/ lansung. Sehingga bisa mencapai tujuan dari pendidikan yaitu mencerdaskan kehidupan bangsa dan negara.

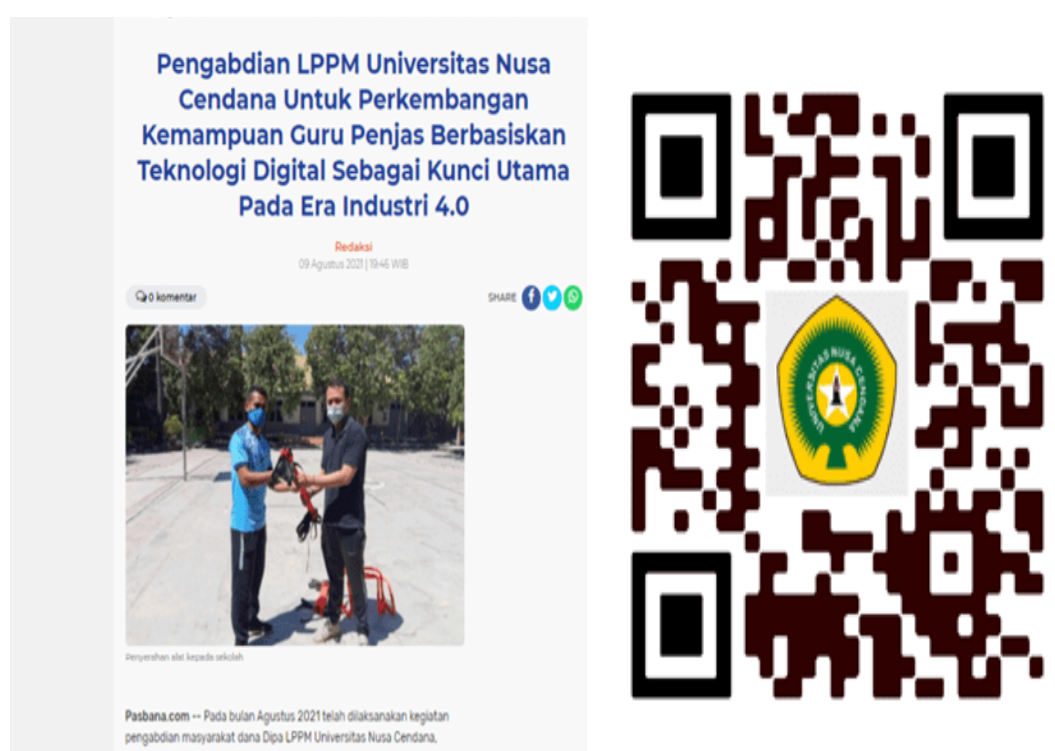

Gambar 4. Berita dan QR code berita media

\section{Diskusi}

Keberhasilan pelaksanaan program pengabdian masyarakat ini dilihat dari dua tolok ukur sebagai berikut :

1. Respons positif dari peserta pelatihan

Respons peserta pelatihan akan diukur melalui observasi selama kegiatan berlangsung dilihat dari antusiasme ketika sesi tanya jawab selama program pengabdian kepada masyarakat ini berlangsung. 
2. Meningkatnya keterampilan peserta setelah mendapat pelatihan dan materi dari pembuatan program latihan yang mana materi itu diberikan ke peserta juga.

3. Partisipasi aktif ketika diberikan kesempatan pada saat evaluasi gerakan

\section{Kesimpulan}

Pemberian pelatihan penggunaan alat hurdle drills dan Ladder Drills bagi guru pendidikan jasmani dalam pembelajaran penjas di Kota Kupang, Nusa Tenggara Timur memberikan dampak positif bagi guru penjaskesrek di tingkat SD, SMP, dan SMA. Selain itu, dengan pelatihan ini dalam bentuk teori dan praktek akan meningkatkan sumber daya siswa. Hal ini disebabkan karena guru yang diberikan pelatihan ini akan memahami secara konteks dan secara praktek sehingga dapat memberikan pemahaman kepada siswanya, maka siswa otomatis akan meningkatkan minat dan motivasi siswa didalam pembelajaran penjas dan ber efek peningkatan kemampuan motorik siswa.

\section{Pengakuan}

Terimakasih kepada LPPM Universitas Nusa Cendana yang mana telah mendanai pengabdian ini sehingga pengabdian ini bisa berjalan dengan baik dari awal sampai tahap akhir. Terimakasih pada sekolah citra bangsa yang menyediakan wadah dan tempat untuk terlaksananya kegiatan ini. Terimakasih pada guru-guru yang terlibat didalam pengabdian ini. Dan terakhir yang mana media yang meliput kegiatan ini dari Pas Bana Media berita elektronik.

\section{Daftar Referensi}

Anderson, L., \& Glover, D. R. (2017). Building Character, Community, And A Growth Mindset In Physical Education: Activities That Promote Learning And Emotional And Social Development. Human Kinetics.

Arif, Y. (2020). Pelatihan Pengembangan Pembelajaran Olahraga Renang Melalui Model Pembelajaran E-Learning Dan Face-To-Face ( Blended Learning ) Dalam Mata Kuliah. 4(2), 246-252. Http://Www.JurnalUmbuton.Ac.Id/Index.Php/Ppm/Article/View/630/648

Arif, Y., Boleng, L. M., Babang, V. M. M. F., \& Saba, K. R. (2019). Pengaruh 
Keseimbangan, Daya Ledak Otot Tungkai, Dan Motivasi Berprestasi Dengan Kemampuan Tendangan Monthong Doliochagi (Vol. 3, Issue 3). Https://Doi.Org/Http://Dx.Doi.Org/10.23887/Ijerr.V2i3.21091.G13182 Brad Stulberg, S. M. (2017). Praise For Peak Performance. Rodale.

Harrison, J. (2017). Essentials Of Physical Education. White Word Publication.

Padmawan, I. P. R., Darmada, I. M., Widiantari, N. L. G., Santika, I. G. P. N. A., Ariawati, N. W., \& Segu, A. D. (2020). Pelatihan Ickey Shuffle Dengan Jarak 6 Meter 4 Repetisi 3 Set Terhadap Kelincahan Siswa Putra Kelas X Sma Negeri 2 Mengwi Badung. Jurnal Pendidikan Kesehatan Rekreasi, 6(1), 119-124. Https://Doi.Org/10.5281/Zenodo.3661606

Piyana, P. D., Subekti, M., \& Santika, . I. G. P. N. A. (2020). Pelatihan Hanging Leg Raise Terhadap Kekuatan Otot Perut. Penjaga : Pendidikan Jasmani \&Amp; Olahraga, 1(1), 7-11. Retrieved From Https://Jurnal.Stkippgritrenggalek.Ac.Id/Index.Php/Penjaga/Article/Vie $\mathrm{w} / 58$

Ruslan. (2011). Meningkatkan Kondisi Fisik Atlet Pusat Pendidikan Dan Latihan Olahraga Pelajar (PPLP) Di Provinsi Kalimantan Timur. Jurnal Ilara (Jurnal Ilmu Olahraga).

Santika, I. G. P. N. A., Pranata, I. K. Y., \& Festiawan, R. (2020). The Effectiveness Of Jogging Sprint Combination Training On Students Fat Levels. Journal Of Physical Education Health And Sport, 7(2), 43-48. Https://Journal.Unnes.Ac.Id/Nju/Index.Php/Jpehs/Article/View/27020

Setiyawan, S. (2017). Kepribadian Atlet Dan Non Atlet. Jendela Olahraga. Https://Doi.Org/10.26877/Jo.V2i1.1289

Sullivan, L. (2015). Health And Physical Education. In The Sage Glossary Of The Social And Behavioral Sciences. Ontario. Https://Doi.Org/10.4135/9781412972024.N1169

Sumarsono, A. (2019). Pengaruh Metode Latihan Agility Hurdle Drill Dan Agility Leader Terhadap Koordinasi Kaki Anggota Ukm Futsal Universitas Musamus Merauke. Altius: Jurnal Ilmu Olahraga Dan Kesehatan. Https://Doi.Org/10.36706/Altius.V6i1.8220

Yusollina, I., \& Suwanda, I. M. (2020). Implementasi Pendidikan Karakter Melalui Kultur Sekolah Di Sman 18 Surabaya. Kajian Moral Dan Kewarganegaraan. 